\title{
Adoption of Mobile Banking in Bangladesh: A Conceptual Framework
}

\author{
Md Shamimul Islama*, Noorliza Kariaba ${ }^{a}$ Mohamed Soliman Mohamed Solimana, \\ Mahmudul Hasan Foujib, Jamshed Khalida, Muhammad Khaleela \\ a School of Management, Universiti Sains Malaysia, Penang, Malaysia. \\ b Assistant Professor, Department of Marketing, Jagannath University, Dhaka, Bangladesh. \\ *Corresponding author's email address: shamimasaub@gmail.com
}

\section{A R T I C L E I N F O}

Received: 11-08-2017

Accepted: 03-10-2017

Available online: $12-10-2017$

Keywords:

Emerging economy;

Bangladesh mobile banking;

Technology adoption;

UTAUT.

JEL Classification:

G21; G28.

\begin{abstract}
A B S T R A C T
The objective of this paper is to present a framework to study the behavioral intention of customers to use mobile banking service in Bangladesh. Though many companies have taken initiatives to make it popular among the customers, there is still no sign of significant progress. It is therefore necessary to understand what factors influence the intentions of customers to adopt mobile banking in Bangladesh. However, there is a lack of scientific frameworks available to adopt for this study purpose. To develop this framework an extensive literature review has been conducted from the scientific journals and from influencial authors in this field. The proposed framework extended the unified theory of acceptance and use of technology (UTAUT) model by integrating two additional variables such as perceived credibility and personal innovativeness. This study presented a proposed framework which has not been tested in an empirical setting. Therefore, an empirical studies need to be performed to identify the fitness of the proposed model. Managers, bankers, practitioners can use this framework to study the behavioral intention of their customers to adopt mobile banking service. Though UTAUT theory has been designed to evaluate the behavioral intention to adopt generic information technology, however specific technology needs some special treatment. For example, UTAUT cannot address all issues related to user acceptance of mobile banking. Therefore, this study extended UTAUT by adding two new variables which are highly relevant for mobile banking industry.
\end{abstract}

This is an open access article under the terms of the Creative Commons Attribution License 4.0, which allows use, distribution and reproduction in any medium, provided the original work is properly cited.

\section{Introduction}

Bangladesh is currently holding world's eight population (Bureau, 2017) making it one of the emerging economies in the South Asian region. But the country is still lagging behind other nations in the SAARC (South Asian Association for Regional Cooperation ) region when it comes to digital infrastructure (Islam, 2013). The digital divide among its neighboring countries also testifies the same result. However, the rapid growth of internet users in Bangladesh has provided ample opportunities for new ventures like e-commerce, m-commerce, ebanking and m-banking. Though some banks have already developed mobile banking platform but this service is yet to get popularity. Additionally, the low rate of mobile banking users in comparison to online buyers clearly demonstrates the lack of intention to use mobile banking.

In contrast, e-commerce operators are showing good performance in Bangladesh, and they said $70 \%$ of their orders are coming from outside the capital city, Dhaka (Kader, 2016). It is an evidence that customers living outside Dhaka have started buying online with their electronic devices. These clients already have access to the 
internet and are aware of online transactions. So, there is an opportunity for banks to extend their mobile banking (m-banking) services outside Dhaka. The objective of this paper is to develop a conceptual framework to identify the factors influencing the intention to use mobile banking in Bangladesh.

Though there are numerous literatures related to the adoption of mobile banking; it is scarce in the Bangladeshi context. Only a handful of studies examined customer preferences on the intention of using mbanking in Bangladesh (Azad, 2016; Hassan et al. , 2014; Islam and Hossain, 2014; Liza, 2014; Parvin, 2015). However, most of the previous studies employed descriptive studies while application of scientific approach can hardly be noticed. Some (Azad, 2016) used neural network analysis to predict mobile banking adoption in Bangladesh. Other studies did not go through proper scientific approach. Thus, there is clearly a literature gap from methodological approach in the Bangladeshi context.

However, this paper has developed the framework based on the unified theory of acceptance and use of technology (UTAUT) (Venkatesh et al. , 2003). Additionally, the study proposed to use structural equation modeling (SEM) to analyze the data. Though UTAUT is a widely practiced method in the behavioral study but the use of this model in asssesssing the intention of customers to use mobile banking is scarce. Addtioionally, this study extended UTAUT model by adding new variables to fit the model in assessing the intention to use mobile banking. So, this study contributes to the existing literature by extending the UTAUT model.

Moreover, previous studies were confined only within Dhaka. As a result, prior studies lack generalizability criteria. This study proposed to capture the data from outside Dhaka city. Data from other cities with diverse sets of people will inevitably provide more rigorous results. Therefore this study has a contribution in existing literature by extending the previous study regarding generalizability.

The rest of the paper is organized as follows: section 2, discussed theoretical background, then, conceptual framework and hypothesese development is presented in section 3 while data and methodology part are discussed in section 3 followed by finding and discussion in section 4. Section 5 provided rational description based on the result and previous literature. Finally, limitations and suggestions for future research are given at Section 6.

\section{Theoretical background}

The implementation of a new technology depends on its acceptance by the users. Therefore the study of the human behavior is the key to implementing any technology. Thus the human behavior has become a pivotal part of the research of information systems. Initially, Different widely accepted models of human behavior had been developed by psychologists. Theory of Reasoned Action (TRA) (Ajzen and Fishbein, 1980) is one of them. Based on this theory, Davis (1989) developed Technology Acceptance Model(TAM). Since human behavior is changing with the passage of time, recent theories become more relevant. Venkatesh et al. (2003) developed a Unified Theory of Acceptance and Use of Technology (UTAUT) model by extending the previous one. He had empirically tested and compared eight prior models such as TRA, TAM, TAM2, Theory of Planned Behavior (TPB), Decomposed Theory of Planned Behavior (DTPB), Combined TAM and TPB (C-TAM-TPB), Innovation Diffusion Theory (IDT), Motivational Model (MM), Model of PC Utilization (MPCU) and Social Cognitive Theory (SCT). He later conducted a longitudinal study, to finally develop the UTAUT model.

The UTAUT model primarily considers four independent variables: performance expectancy, effort expectancy, social influence and facilitating conditions whereas the intention to use technology is taken as the dependent variable. Additionally, it showed that the relationship between independent and dependent factors is moderated by different demographic variables like gender, age, experience, and voluntariness. This study adopted this model as the basis of the research model. In addition to this model. Current study adapted perceived credibility construct (Luarn and Lin, 2005) from mobile banking literature to make this model fit for the study in the current context. This study does not test the UTAUT model but rather it adopted certain factors to identify the level of intention among consumers to adopt mobile banking in Bangladesh.

\section{Proposed framework and hypothesis}

\subsection{Performance expectancy}

Performance expectancy has been derived from perceived usefulness (TAM/TAM2), the relative advantage (IDT), job-fit (MPCU), extrinsic motivates (MM), and outcome expectations (SCT) in the UTAUT model (Venkatesh et al. , 2003). Performance expectancy refers to the degree to which using technology will provide benefits to consumers in performing certain activities. Previous studies found this variable as significant predictor for the behavioral intention of consumers (Brown et al. , 2003; Luarn and Lin, 2005; Park et al. , 2007). Since past studies have found a significant relationship between performance expectancy and intention to use mobile banking, this study developed the following hypothesis based on that:

H1: Performance expectancy has a significant impact on the intention to use mobile banking 


\subsection{Effort expectancy}

Effort expectancy has been developed as part of the evolution of past constructs like perceived ease of use by TAM, complexity by MPCU and ease of use by IDT. Effort expectancy refers to the degree of ease associated with consumers' use of technology. Literature suggests that many past studies had used these constructs to identify behavioral intention to use mobile banking in different countries (Amin et al. , 2008; Lu et al. , 2009; Luarn and Lin, 2005; Park et al. , 2007). These studies found a significant relationship between the effort expectancy and intention to use mobile banking. Therefore this study rationally developed another hypothesis based on the previous findings:

H2: Effort expectancy has a significant impact on the intention to use mobile banking.

\subsection{Social influence}

Social influence construct has also been developed as part of the evolution of relevant past constructs such as subjective norm from TRA, TAM2, TPB/DTPB and C-TAM-TPB, social factors from MPCU and image from IDT. Social influence implies the extent to which consumers believe that their friends and families should influence the use of a particular technology. Previous studies also tested the relationship between social influence and behavioral intention to use mobile banking(Singh et al. , 2010; van Gelderen and Bik, 2016; Yu, 2012). They found social influence as a strong predictor for intention to use mobile banking. Based on these findings the current study rationally developed yet another hypothesis:

H3: Social influence has a significant impact on the intention to use mobile banking.

\subsection{Facilitating conditions}

Facilitating condition construct has emerged from its predecessor constructs like perceived behavioral control from TPB/DTPB, C-TAM-TPB, facilitating conditions from MPCU and compatibility from IDT(Venkatesh et al. , 2003). Facilitating conditions refers to consumers' perceptions of the resources and support available to perform a behavior. To make the mobile technology available to customers, the facilitating conditions like the access of respondents to computer and Internet are necessary (Joshua and Koshy, 2015). Previous studies also tested the relationship between facilitating conditions and the intention to use mobile banking $(\mathrm{Yu}, 2012)$ and found a strong correlation. Thus this study employed another hypothesis as below:

H4: Facilitating conditions significantly affects individual intention to use mobile banking.

\subsection{Perceived credibility}

This construct did not come from UTAUT model. The literature on mobile banking suggests that additional variables might influence the consumers to adopt this technology. Perceived credibility is one of those variables that previous researchers used in their studies to identify the behavioral intention to use mobile banking (Amin et al. , 2008; Lu et al. , 2009; Luarn and Lin, 2005; Park et al. , 2007). Previous studies had identified safety and security concern as the key factor influencing the behavior to use mobile banking. For example, fear of disseminating personal data, lack of encryption of the messages, etc. was among security concerns Luarn and Lin, 2005). Furthermore, other studies have found that consumers' trust plays a vital role in the adoption of mobile banking (Amin et al. , 2008; Brown et al. , 2003; Laforet and Li, 2005). Because the risk associated with mobile banking highly demotivate the consumer behavior to accept mobile banking (Yu, 2012). Past studies had tested perceived credibility construct empirically and found it as a strong predictor for intention to use mobile banking. Thus the current study developed another hypothesis accordingly:

H5: Perceived credibility significantly affects individual intention to use mobile banking.

\subsection{Personal Innovativeness (PI)}

Agarwal and Prasad (1998) defined it as the individual's willingness to try out any new information technology. Innovation diffusion Theory (IDT) by Rogers (2003) suggests that individuals with a high level of innovativeness are more willing to adopt positive ideas and changes in new IT and have more capacity to deal with uncertainty compared with those with a lower level (Lu et al. , 2005). If individuals are more likely to try new IT, then they can act as change agents and opinion leaders for new IT implementation in organizational settings (Agarwal and Prasad, 1998). Several studies investigated the effect personal innovativeness has on a new IT behavioral intention (Abu-Al-Aish and Love, 2013; Fang et al. , 2009; Hung and Chang, 2005; Lian and Lin, 2008; Lu et al. , 2005).

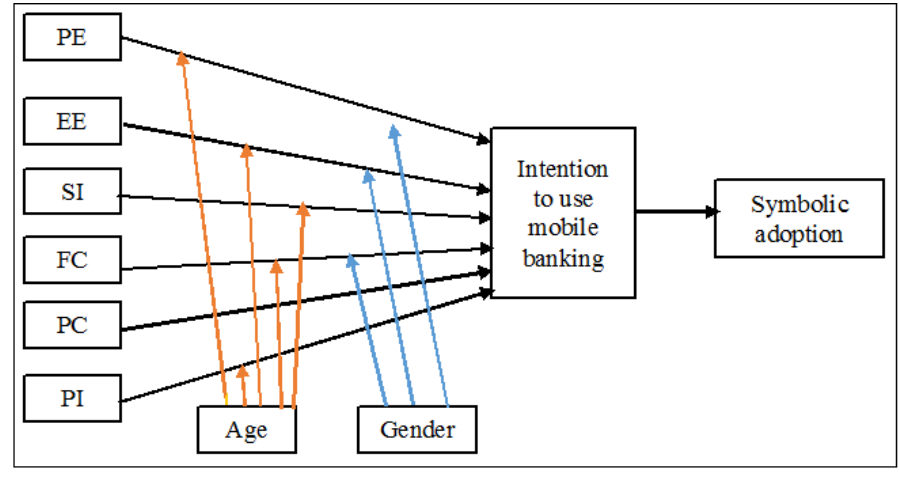

Figure 1: Proposed research model. (Adapted from UTAUT by Venkatesh 2003), PE: Performance expectancy; EE: Effort expectancy; SI: Social influence; FC: Facilitating condition; PC: Perceived credibility; PI: Personal Innovativeness 
H6: Personal innovativeness has a positive effect on behavioral intention to use Mobile banking services. Intention to use mobile banking services

Intention to use Mobile banking services is the behavioral intention of the people of an organization to use the Mobile banking services within organizational setting and subsequently refers to the actual use of that Mobile banking services. In the literature, several studies used the same dependent variable in the past (AmoakoGyampah, 2007; Amoako-Gyampah and Salam, 2004; Ramayah and Lo, 2007).

Literature suggests that there is a strong correlation between behavioral intention and actual behavior (Venkatesh and Davis 2000). Thus, the people will use the Mobile banking services when they have higher perceived ease of use. Additionally, Amoako-Gyampah and Salam (2004) emphasized to examine the behavioral intention to use system when the usage might be mandatory. Therefore, in these circumstances, behavioral intention can be viewed as the likelihood that a user will utilize Mobile banking services in the future. Thus, this construct was adopted for this research endeavor indicating that end-users intend to utilize Mobile banking services.

\subsection{Outcome: Symbolic adoption}

Symbolic adoption indicates end user acceptance of mandatory technology (Govindaraju and Indriany, 2007; Nah et al. , 2004; Seymour et al. , 2007). Recently, Symbolic Adoption has been measured in adoption of other information studies (Al-Jabri and Roztocki, 2015; AlHirz and Sajeev, 2013; Mahmud et al. , 2017; Mouakket, 2012). Less user resistance and high user acceptance will lead to higher level of Symbolic Adoption in mandatory complex information system (Wang and Hsieh, 2006). However, symbolic adoption may varies in different situations. For example, most of the previous studies conducted on the user acceptance of mandatory technology in the organizations. Mobile banking adoption is not a mandatory technology, rather it is more voluntary nature. Users have the option either accept or reject the technology. Thus, this study predict that symbolic adoption will work in voluntary situation as well. About symbolic adoption, Wang et al. (2014) explained individuals within the organization with high symbolic adoption is more likely to invest time and effort to engage in system learning. As a result, the study employed the following hypothesis:

H7: User intention to use Mobile banking services has a positive impact on symbolic adoption of user.

\subsection{The Moderating Effect}

\subsubsection{Moderator effects - Age}

Venkatesh et al. (2003) argued that literature found that younger people is focusing more on extrinsic rewards. In contrast, it is hard to find older people to accept and adopt new system. Similarly, older people tend to give low effort to learn a new system. Consequently, older people have lower performance expectancy because they are giving less effort to learn new system. Additionally, they do not believe that increase effort will increase their job performance. Venkatesh et al. (2003) identified age as a moderating variable for the following relationship:

H9: The influence of personal innovativeness on user intention will be moderated by age.

H10: The influence of performance expectance on user intention will be moderated by age.

H11: The influence of effort expectance on user intention will be moderated by age.

H12: The influence of social influence on user intention will be moderated by age.

H13: The influence of facilitating conditions on user intention will be moderated by age.

\subsection{Moderator effects - Gender}

Literature suggests that gender has a moderating effect on the behavioral intention to use new system. For example, Venkatesh et al. (2000) argued that male and female exhibited different results on the use of information system in different situations. Literature related to gender differences found that men are highly task oriented than female. Thus, men have higher performance expectations in those works that are highly task accomplishment oriented (Venkatesh et al. , 2003). On the other hand, female people were found as less task oriented. Additionally, they exhibited higher level of computer anxiety comparing with their male colleagues. Like Venkatesh et al. (2003) this study use gender as moderator for the following relationships:

H14: The influence of performance expectance on user intention will be moderated by gender.

H15: The influence of effort expectance on user intention will be moderated by gender.

H16: The influence of facilitating conditions on user intention will be moderated by gender.

\section{Methodology}

This research is a part of a multi-phased research aiming to investigate the use of Mobile banking services in Bangladesh. The goal of this research is to identify the factors that affecting the intention to use Mobile banking services among people in Bangladesh. This research proposes the conceptual model by extension the Unified Theory of Acceptance and Use of Technology (UTAUT) by adding two new variables perceived credibility and personal innovativeness. To identify published articles pertaining to intention to use of Mobile banking services, 
this search involved various databases (e.g., ACM, Emerald, IEEE, Inderscience, Science Direct, Taylor \& Francis, Wiley) and multiple relevant key terms, such as Mobile banking services adoption, Mobile banking services user's acceptance, Mobile banking services behavior intention and intention to use Mobile banking services. Additionally, the hypotheses are developed with the table of constructs and measurement items. Hypothesis will be tested by quantitative method that based on the questionnaires that will be distributed to collect data from people in Bangladesh. Finally, in order to generate the integrated model, Structural Equation Model (SEM) will be applied to analyze the data collected.

\subsection{The measures}

Table 1 represents the measure structure for assessing the behavioral intention of the users to adopt mobile banking service. The table presented different constructs or variables along with their corresponding items.

Table 1: The measures

\begin{tabular}{|c|c|c|}
\hline Construct & Corresponding Items & Items Sources \\
\hline Performance & In conducting banking affairs, & \\
\hline Expectancy & $\begin{array}{l}\text { (PE1) using mobile banking would improve my performance } \\
\text { (PE2) using mobile banking would save my time } \\
\text { (PE3) I would use mobile banking anyplace } \\
\text { (PE4) I would find mobile banking useful }\end{array}$ & $\begin{array}{l}\text { Luarn and Lin (2005) } \\
\text { Venkatesh et al. (2003) }\end{array}$ \\
\hline Effort & (EE1) Learning to use mobile banking is easy for me & Venkatesh et al. (2003) \\
\hline Expectancy & $\begin{array}{l}\text { (EE2) Becoming skilful at using mobile banking is easy for me } \\
\text { (EE3) Interaction with mobile banking is easy for me } \\
\text { (EE4) I find mobile banking is easy to use }\end{array}$ & $\begin{array}{l}\text { Venkatesh and Zhang } \\
\text { (2010) and Luarn and } \\
\text { Lin (2005) }\end{array}$ \\
\hline Social & (SI1) People who are important to me think that I should use & Venkatesh et al. (2003) \\
\hline Influence & $\begin{array}{l}\text { mobile banking } \\
\text { (SI2) People who are familiar with me think that I should use } \\
\text { mobile banking } \\
\text { (SI3) People who influence my behavior think that I should use } \\
\text { mobile banking } \\
\text { (SI4) Most people around me use mobile banking }\end{array}$ & $\begin{array}{l}\text { Venkatesh and Zhang } \\
\text { (2010) and Luarn and } \\
\text { Lin (2005) }\end{array}$ \\
\hline Perceived & When using mobile banking, & Luarn and Lin (2005) \\
\hline Credibility & $\begin{array}{l}\text { (PC1) I believe my information is kept confidential } \\
\text { (PC2) I believe my transactions are secured } \\
\text { (PC3) I believe my privacy would not be divulged } \\
\text { (PC4) I believe the banking environment is safe }\end{array}$ & Brown et al. (2003) \\
\hline $\begin{array}{l}\text { Personal } \\
\text { Innovativeness }\end{array}$ & $\begin{array}{l}\text { PInn1. I like to experiment with new information technologies. } \\
\text { PInn2. When I hear about a new information technology, I look } \\
\text { forward to examining it. } \\
\text { PInn3. Among my colleagues, I am usually the first to try out a } \\
\text { new innovation in technology. }\end{array}$ & $\begin{array}{l}\text { Agarwal and Prasad } \\
\text { (1998) } \\
\text { Abu-Al-Aish and Love } \\
\text { (2013) }\end{array}$ \\
\hline Facilitating & (FC1) My living environment supports me to use mobile banking & Venkatesh et al. (2003) \\
\hline Conditions & $\begin{array}{l}\text { (FC2) My working environment supports me to use mobile } \\
\text { banking } \\
\text { (FC3) Using mobile banking is compatible with my life } \\
\text { (FC4) Help is available when I get problem in using mobile } \\
\text { banking }\end{array}$ & $\begin{array}{l}\text { Venkatesh and Zhang } \\
\text { (2010) and Luarn and } \\
\text { Lin (2005) }\end{array}$ \\
\hline $\begin{array}{l}\text { Intention to use } \\
\text { Mobile Banking }\end{array}$ & $\begin{array}{l}\text { When dealing with banking affairs } \\
\text { (ITU1) I prefer to using mobile banking } \\
\text { (ITU2) I intend to use mobile banking } \\
\text { (ITU3) I would use mobile banking }\end{array}$ & $\begin{array}{l}\text { Venkatesh et al. (2003) } \\
\text { Venkatesh and Zhang } \\
\text { (2010) Luarn and Lin } \\
\text { (2005) and } \\
\text { Sripalawat et al. (2011) }\end{array}$ \\
\hline $\begin{array}{l}\text { Intention } \\
\text { to use }\end{array}$ & $\begin{array}{l}\text { When dealing with work } \\
\text { ITU1. I prefer to use ERP system } \\
\text { ITU2. I intend to use ERP system } \\
\text { ITU3. I would use ERP system }\end{array}$ & $\begin{array}{l}\text { Venkatesh et al. (2003) } \\
\text { Venkatesh and Zhang } \\
\text { (2010) Luarn and Lin } \\
\text { (2005) } \\
\text { Sripalawat et al. (2011) }\end{array}$ \\
\hline $\begin{array}{l}\text { Symbolic } \\
\text { adoption }\end{array}$ & $\begin{array}{l}\text { SA1. I am enthusiastic about using ERP } \\
\text { SA2. I am exciting about using ERP } \\
\text { SA3. It is my desire to see full implementation of ERP system }\end{array}$ & $\begin{array}{l}\text { Nah et al. (2004) } \\
\text { Seymour et al. (2007) } \\
\text { AlHirz and Sajeev } \\
(2013)\end{array}$ \\
\hline
\end{tabular}




\section{Conclusion, limitations and future research}

The practice of mobile banking in Bangladesh has emerged as a new phenomenon because of increased digitalization process in the country. Digitalization of the country has lead to a boom in e-business, e-commerce, e-government, m-banking or mobile banking etc. However, mobile banking has not been able to gain as many users as e-commerce. Therefore, a study was necessary to explore the causes of this apparent inconsistency. However, lack of scientific research in this context left no existing framework by which a study could be conducted to identify the possible factors. Thus, this study proposed a new framework to study the intention of the customers to adopt mobile banking services in the country.

The study extensively reviewed existing theories such as TRA, TPB, TAM, UTAUT etc. to developed this framework. This study added perceived credibility and personal innovativeness factors as new variables in the framework. Perceived credibility assesses the people's trust on the service. Specially the security concern. If the security is high people tend to show high trust on the system. Security concern is a major threat that hinders the growth of mobile banking in Bangladesh. For example, many customers have lost their money due to poor security system(Moretaza, 2015) of Bkash, arguably the most popular mobile banking service in Bangladesh. Therefore the inclusion of this factor in the framework is justified. On the other hand personal innovativeness factor will assess how much dynamic the people are to try out a new technology. These two variable will enhance the measurement framework for assessing users intention to adopt mobile banking.

Mobile banking in Bangladesh has opened the door to green growth. Because mobile banking operates on digital platform, it thereby reduces the use of paper. Since green initiative leads to sustainability, mobile banking can easily be considered as a green initiative. As a result, mobile banking will result in sustainable development of the country. In addition, many studies have found that investment in digitalization had increased economic growth and women empowerment(Islam, 2015). Therefore, this study has a significant contribution to the policy makers and practitioners.

Currently, there are 131 million mobile subscribers in Bangladesh(BTRC, 2016). This number shows the huge potentiality of mobile banking in this country. Youth are the main users of mobile banking. Demographic statistics also indicates that significant portion of the total population are youth. Hence, Bangladesh has high prospects in the mobile banking sector. Unfortunately, because of the absence of security, awareness, and incentives; customers are still reluctant to adopt mobile banking.

This study proposed to use age and gender as moderator. Many studies already used gender and age as moderators in studying the behavioral intention of people to adopt new technology. All studies have found that there are differences in how males and females perceived a new technology. Additionally, there are difference in age groups to adopt a new technology. Thus, it is well established that gender and age have moderating effect in the relationship between independent and dependent variables. However, besides these moderators future studies can employ even more moderators such as internet anxiety, educational qualifications, experience, etc.

The study has some limitations. First, this study presented a proposed framework which has not been tested in an empirical setting. There might me collinearity problems among the latent variables. Because the framework integrated two new variables in original UTAUT model. Therefore, an empirical studies need to be performed to identify the fitness of the proposed model.

Second, this study adopted the UTAUT theory by adding only two additional factors. Besides these factors, there might be some additional latent factors that may also influence the behavior of the customers in adopting mobile banking. So future studies can explore those other factors by explorative studies or by using other information system (IS) theories.

\section{References}

Abu-Al-Aish, A., \& Love, S. (2013). Factors influencing students' acceptance of m-learning: an investigation in higher education. The International Review of Research in Open and Distributed Learning, 14(5).

Agarwal, R., \& Prasad, J. (1998). A conceptual and operational definition of personal innovativeness in the domain of information technology. Information systems research, 9(2), 204-215.

Ajzen, I., \& Fishbein, M. (1980). Understanding attitudes and predicting social behaviour.

Al-Jabri, I. M., \& Roztocki, N. (2015). Adoption of ERP systems: Does information transparency matter? Telematics and Informatics, 32(2), 300-310.

AlHirz, H., \& Sajeev, A. (2013). Factors influencing symbolic adoption of ERP systems in the Middle-East. Paper presented at the Enterprise Systems Conference (ES), 2013.

Amin, H., Hamid, M. R. A., Lada, S., \& Anis, Z. (2008). The adoption of mobile banking in Malaysia: The case of Bank Islam Malaysia Berhad (BIMB). International Journal of Business and Society, 9(2), 43.

Amoako-Gyampah, K. (2007). Perceived usefulness, user involvement and behavioral intention: an empirical study of ERP implementation. Computers in Human Behavior, 23(3), 1232-1248.

Amoako-Gyampah, K., \& Salam, A. F. (2004). An extension of the technology acceptance model in an ERP implementation environment. Information \& Management, 41(6), 731-745.

Azad, M. A. K. (2016). Predicting mobile banking adoption in Bangladesh: a neural network approach. Transnational Corporations Review, 8(3), 207-214. 
Brown, I., Cajee, Z., Davies, D., \& Stroebel, S. (2003). Cell phone banking: predictors of adoption in South Africaan exploratory study. International journal of information management, 23(5), 381-394.

BTRC. (2016). Mobile phone scribers in Bangladesh. The total number of Mobile Phone subscriptions has reached 131.085 million at the end of February, 2016. Retrieved from http://www.btrc.gov.bd/content/mobilephone-subscribers-bangladesh-february-2016

Bureau, U. S. C. (2017). U.S. Census Bureau Current Population World Population. Retrieved from https://www.census.gov/popclock/print.php?component=counter

Davis, F. D. (1989). Perceived usefulness, perceived ease of use, and user acceptance of information technology. MIS quarterly, 319-340.

Fang, J., Shao, P., \& Lan, G. (2009). Effects of innovativeness and trust on web survey participation. Computers in Human Behavior, 25(1), 144-152.

Govindaraju, R., \& Indriany, N. (2007). A Study on ERP system accertance based on technology acceptance model.

Hassan, M., Rahman, A., Afrin, S., \& Rabbany, M. G. (2014). Factors Influencing the Adoption of Mobile Banking Services in Bangladesh: An Empirical Analysis. International Research Journal of Marketing, 9-20.

Hung, S.-Y., \& Chang, C.-M. (2005). User acceptance of WAP services: test of competing theories. Computer Standards \& Interfaces, 27(4), 359-370.

Islam, M. M., \& Hossain, M. E. (2014). Consumers' Attitudes towards Mobile Banking in Bangladesh. Paper presented at the The Second International Conference on E-Technologies and Business on the Web (EBW2014).

Islam, M. S. (2013). Digital Divide \& Its Impact on Economic Growth in SAARC Countries. IJAR BAE, 2(2), 14-26.

Islam, M. S. (2015). Impact of ICT on women empowerment in South Asia. Journal of Economic \& Financial Studies, 3(03), 80-90.

Joshua, A., \& Koshy, M. P. (2015). Usage patterns of electronic banking services by urban educated customers: Glimpses from India. The Journal of Internet Banking and Commerce, 2011.

Kader, R. (2016). Future Startup. Inside Ajkerdeal's Big Plan To Take e-Commerce Beyond Dhaka Retrieved from http:// futurestartup.com/2016/12/19/inside-ajkderdeals-big-plan-take-e-commerce-beyond-dhaka/

Laforet, S., \& Li, X. (2005). Consumers' attitudes towards online and mobile banking in China. International journal of bank marketing, 23(5), 362-380.

Lian, J.-W., \& Lin, T.-M. (2008). Effects of consumer characteristics on their acceptance of online shopping: Comparisons among different product types. Computers in Human Behavior, 24(1), 48-65.

Liza, F. Y. (2014). Factors Influencing the Adoption of Mobile Banking: Perspective Bangladesh. Global Disclosure of Economics and Business, 3(2), 199-220.

Lu, J., Yao, J. E., \& Yu, C.-S. (2005). Personal innovativeness, social influences and adoption of wireless Internet services via mobile technology. The Journal of Strategic Information Systems, 14(3), 245-268.

Lu, J., Yu, C.-S., \& Liu, C. (2009). Mobile data service demographics in urban China. Journal of Computer Information Systems, 50(2), 117-126.

Luarn, P., \& Lin, H.-H. (2005). Toward an understanding of the behavioral intention to use mobile banking. Computers in Human Behavior, 21(6), 873-891.

Mahmud, I., Ramayah, T., \& Kurnia, S. (2017). TO USE OR NOT TO USE: MODELLING END USER GRUMBLING AS USER RESISTANCE IN PRE-IMPLEMENTATION STAGE OF ENTERPRISE RESOURCE PLANNING SYSTEM. Information Systems.

Moretaza, T. (2015). The Independent. bKash customers at risk. Retrieved from http://www.theindependentbd.com/printversion/details/16444

Mouakket, S. (2012). Extending the technology acceptance model to investigate the utilization of ERP systems Enterprise Information Systems and Advancing Business Solutions: Emerging Models (pp. 1-18): IGI Global.

Nah, F. F.-H., Tan, X., \& Teh, S. H. (2004). An empirical investigation on end-users' acceptance of enterprise systems. Information Resources Management Journal (IRMJ), 17(3), 32-53.

Park, J., Yang, S., \& Lehto, X. (2007). Adoption of mobile technologies for Chinese consumers. Journal of Electronic Commerce Research, 8(3), 196.

Parvin, A. (2015). Mobile banking operation in Bangladesh: prediction of future. The Journal of Internet Banking and Commerce, 2013.

Ramayah, T., \& Lo, M.-C. (2007). Impact of shared beliefs on "perceived usefulness" and "ease of use" in the implementation of an enterprise resource planning system. Management Research News, 30(6), 420-431.

Rogers, E. M. (2003). Diffusion of Innovations, 5th Edition: Free Press.

Seymour, L., Makanya, W., \& Berrangé, S. (2007). End-users'acceptance of enterprise resource planning systems: An investigation of antecedents. Paper presented at the Proceedings of the 6th annual ISOnEworld conference.

Singh, S., Srivastava, V., \& Srivastava, R. (2010). Customer acceptance of mobile banking: A conceptual framework. Sies journal of management, $7(1), 55$.

Sripalawat, J., Thongmak, M., \& Ngramyarn, A. (2011). M-banking in metropolitan Bangkok and a comparison with other countries. Journal of Computer Information Systems, 51(3), 67-76. 
van Gelderen, B. R., \& Bik, L. W. (2016). Affective organizational commitment, work engagement and service performance among police officers. Policing: An International Journal of Police Strategies \& Management, 39(1), 206-221.

Venkatesh, V., \& Davis, F. D. (2000). A theoretical extension of the technology acceptance model: Four longitudinal field studies. Management science, 46(2), 186-204.

Venkatesh, V., Morris, M. G., \& Ackerman, P. L. (2000). A longitudinal field investigation of gender differences in individual technology adoption decision-making processes. Organizational behavior and human decision processes, 83(1), 33-60.

Venkatesh, V., Morris, M. G., Davis, G. B., \& Davis, F. D. (2003). User acceptance of information technology: Toward a unified view. MIS quarterly, 425-478.

Venkatesh, V., \& Zhang, X. (2010). Unified theory of acceptance and use of technology: US vs. China. Journal of Global Information Technology Management, 13(1), 5-27.

Wang, W., \& Hsieh, J. (2006). Beyond routine: Symbolic adoption, extended use, and emergent use of complex information systems in the mandatory organizational context.

Wang, W., Liu, L., Feng, Y., Shao, Z., \& Gao, L. (2014). Comprehensive Understanding the Inhibitors and Enablers of Knowledge Transfer in ERP Assimilations: a Multi-Case Study. Paper presented at the PACIS.

Yu, C.-S. (2012). Factors affecting individuals to adopt mobile banking: Empirical evidence from the UTAUT model. Journal of Electronic Commerce Research, 13(2), 104. 